STUDI

FRANCESI

\section{Studi Francesi}

Rivista quadrimestrale fondata da Franco Simone

152 (니 | II) | 2007

Varia

\title{
Christine Noille-Clauzade, L'Éloquence du Sage. Platonisme et rhétorique dans la seconde moitié du XVII siècle
}

Sabine Lardon

\section{CpenEdition}

Journals

\section{Édition électronique}

URL : https://journals.openedition.org/studifrancesi/45764

DOI : 10.4000/studifrancesi.45764

ISSN : 2421-5856

Éditeur

Rosenberg \& Sellier

\section{Édition imprimée}

Date de publication : 1 octobre 2007

Pagination : 426

ISSN : 0039-2944

\section{Référence électronique}

Sabine Lardon, « Christine Noille-Clauzade, L'Éloquence du Sage. Platonisme et rhétorique dans la seconde moitié du xvII èiècle», Studi Francesi [En ligne], 152 (LI | II) | 2007, mis en ligne le 30 novembre 2015, consulté le 24 novembre 2021. URL : http://journals.openedition.org/studifrancesi/45764; DOI : https://doi.org/10.4000/studifrancesi.45764

Ce document a été généré automatiquement le 24 novembre 2021.

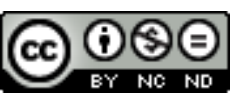

Studi Francesi è distribuita con Licenza Creative Commons Attribuzione - Non commerciale - Non opere derivate 4.0 Internazionale. 


\title{
Christine Noille-Clauzade,
} L'Éloquence du Sage. Platonisme et rhétorique dans la seconde moitié du
$X V I I^{\mathrm{e}}$ siècle

\author{
Sabine Lardon
}

\section{RÉFÉRENCE}

CHRISTINE NOILLE-CLAUZADE, L'Éloquence du Sage. Platonisme et rhétorique dans la seconde moitié du XVII siècle, Paris, Champion, 2004, pp. 337.

1 Cet ouvrage d'une spécialiste de la rhétorique contribue à nous éclairer sur la manière dont Platon est reçu durant l'époque classique qui marque, de manière générale, le déclin de son influence entre les deux temps forts que sont la Renaissance et les Lumières. C'est par le biais d'une démarche rhétorique morale et philosophique fondée sur la dialectique et le dialogue (dont le scepticisme est tour à tour apprécié puis rejeté), mais aussi par la pratique stylistique atticiste d'une prose élevée que Platon parvient encore à séduire. Cet ouvrage suit l'influence rhétorique et poétique du platonisme et son évolution en fonction des courants culturels qui marquent la seconde partie du siècle à travers trois étapes (années 1640-1650, 1670 et 1700) que présente l'introduction.

2 Le chapitre 1 part du renouveau platonicien à la Renaissance et de la lecture symbolique et allégorique (appuyée sur les mythes) qui en est faite, pour dresser ensuite l'état du platonisme au xvii siècle, en France, mais aussi en Europe. L'Age classique marque un mouvement de recul de la philosophie platonicienne, particulièrement perceptible chez les Modernes. Recul doctrinal, nuancé toutefois par la reconnaissance d'un Platon sceptique (avec le cartésianisme), puis par la lecture chrétienne de la métaphysique platonicienne (sous l'influence de saint Augustin), dans 
une fin de siècle marquée par le mouvement dévot et l'augustinisme. Le chapitre 2 montre comment ce rejet doctrinal du platonisme se voit contrebalancé surtout par son intérêt rhétorique, en particulier à partir des années 1670. À travers la critique (élogieuse ou contrastée) qu'en font les rhéteurs grecs ou latins, «l'âge de l'éloquence» retient de la rhétorique platonicienne l'image d'un style poétique élevé (caractérisé par l'abondance de l'invention, la beauté des tropes et la douceur du rythme).

Consacré à La Fontaine, le chapitre 3 part de la publication, en 1685, des Ouvrages de prose et de poésie des sieurs de Maucroix et de La Fontaine, qui comprennent trois dialogues de Platon traduits par Maucroix et participent à ce titre de la Querelle des Anciens et des Modernes. Marqué par l'influence de Jean Racine, le «philhellénisme mondain» de La Fontaine (p. 109) et son goût pour Platon et les Anciens, perpétuent, au xvii siècle, le néo-platonisme allégorique de la Renaissance et se répercutent sur son œuvre littéraire. À travers les positions de La Mothe Le Vayer, Guez de Balzac et Bossuet, le chapitre 4 montre comment, dans la seconde partie du xvii ${ }^{\mathrm{e}}$ siècle, la survie de Platon dans la rhétorique classique est tributaire de l'atticisme de Socrate, chez qui l'on apprécie un modèle de rhétorique à la mesure de l'homme et la modélisation sceptique de l'énonciation. Le chapitre 5 se consacre à La Bruyère. Selon Ch. Noille-Clauzade, celui-ci oppose nettement l'idéalisme platonicien qu'il récuse et le modèle socratique d'une rhétorique à portée morale qui influence la démarche des Caractères. L'auteur montre comment La Bruyère conjugue l'ironie socratique et le cynisme particulièrement influent au xvii siècle - et élève un texte profane à la dignité d'un texte sacré en invitant à une lecture herméneutique, inspirée du goût renaissant pour l'interprétation allégorique, mais surtout de la démarche théologique.

4 Le chapitre 6 dresse l'état de la rhétorique platonicienne dans les années 1670, marquées par le mouvement dévot. Le scepticisme du philosophe n'est plus d'actualité et c'est désormais la dimension morale de sa démarche rhétorique que l'on retient. Cette évolution s'appuie sur un renouveau théorique dont Claude Fleury peut apparaître comme le premier acteur. Le chapitre 7 étudie, pour les comparer, les positions de Fleury et de Fénelon; le premier valorisant chez Platon la dimension philosophique d'une rhétorique fondée sur la dialectique et le dialogue, le second appréciant la rhétorique socratique «à la mesure de l'homme» et une stylistique platonicienne du pathos et de la douceur. Le dernier chapitre se consacre alors au Télémaque de Fénelon, pour étudier l'impact du platonisme dans les dernières années du siècle.

Une bibliographie et un index des noms complètent cette enrichissante étude servie par un développement rigoureux dont le lecteur appréciera la cohérence et la clarté. 